3. Ved MV., Sakhnenko N.D., Karakurkchi A.V., Yermolenko I.Yu. Electroplating and functional properties of Fe-Mo and Fe-Mo-W coatings. Issues of Chemistry and Chemical Technology. 2014. No 5-6. P. 53-60.

4. Sakhnenko M., Karakurkchi A., Galak A., Menshov S., Matykin O. Examining the formation and properties of $\mathrm{TiO}_{2}$ oxide coatings with metals of iron triad Eastern-European Journal of Enterprise Technologies. 2017. Vol. 2,No. 11(86). P. 4-10.

5. ParsadanovI. V., SakhnenkoM. D., KhyzhnyakV. O., Karakurkchi H. V. Improving the environmental performance of engines by intra-cylinder neutralization of toxic exhaust gases. Internal Combustion Engines. 2016. No 2. P. 63-67.

DOI https://doi.org/10.30525/978-9934-26-183-1-8

\title{
ОЦІНКА АНТРОПОГЕННОГО НАВАНТАЖЕННЯ НА ПРИКЛАДІ РІЧКИ АЛЬТА
}

\author{
Ковальська М. \\ студент \\ Національний медичний університет імен. О. О. Богомольия \\ м. Київ, Украӥна \\ Дзюбенко О. В. \\ кандидат біологічних наук \\ Університет Григорія Сковороди в Переяславі \\ Новікова І. П. \\ асистент \\ Національний медичний університет імені О. О. Богомольия \\ м. Київ, Украӥна
}

В останні десятиріччя спостерігається посилення негативного впливу на якісний стан водних ресурсів таких чинників як зміна клімату, активне землекористування, антропогенне та техногенне забруднення води, зростаюче водоспоживання [1, с. 50]. Велику кількість шкідливих речовин та стічних вод, отримує річка Альта. Природні водотоки зазнають значного антропогенного навантаження у першу чергу за рахунок поверхневого стоку з сільськогосподарських територій, а також 
3 боку промислових та комунальних підприємств. Забруднення поверхневих вод річки Альта, негативно впливає на гідрохімічні показники, де вода використовується для питного водопостачання [2, c. 110].

Опису особливостей водних екологічних об'єктів та оцінці якості поверхневих вод присвячені ряд публікацій вітчизняних та зарубіжних науковців [3, с.200; 4, с.17; 5, с.78; 6, с.85; 7, с.420]. Аналіз літературних джерел підтвердив недостатню вивченість процесів формування та функціонування техногенно змінених водних екосистем.

Актуальність досліджуваної теми зумовлена, з одного боку, великим інтересом до теми забруднення річок у сучасній екологічній науці в цілому, а з іншого - недостатнім вивченням стану поверхневих вод безпосередньо р. Альта, оскільки відсутні будь-які наукові праці, які б розкривали причини їі деградації. Отже, вивчення питань, пов'язаних 3 цією тематикою, має як теоретичну, так і практичну значущість.

Мета дослідження - проаналізувати загальний стан та експериментально оцінити токсичність поверхневих вод р. Альта в межах м. Переяслав за допомогою «Ростового тесту» .

Об'скт дослідження - процеси забруднення та деградації водної екосистеми р. Альта в межах м. Переяслав.

Методи дослідження. Для вирішення наукових і методологічних завдань застосовувались методи статистичного оброблення, аналізу, натурного спостереження, синтезу, метод «Ростового тесту» та узагальнення даних екологічного моніторингу стану водної екосистеми р. Альта в межах м. Переяслав.

У ході аналізу проростання біоіндикаторної культури (Triticum vulgare $L$ ) від токсичності відібраних проб річкової води на відстані 500 м до умовного джерела скиду, 500 м, 1000 м та 1500 м після скиду стічних вод було встановлено, що в контрольному зразку проросла 21 насінина біоіндикаторної культури, при цьому на дослідній ділянці № 1 кількість пророслих насінин складало від 9 шт. (проба відбору 1000 м) до 24 шт. (після 500 м).

На трьох точках відбору спостерігається пригнічення ростових процесів (до 500 м, 1000 м та 1500 м після скиду стічних вод) порівнянні 3 контролем. При цьому на точці відбору (після 500 м) спостерігається значне стимулювання ростових процесів та складає 24 насінини.

Отже, при дослідженні середнього значення кореневої частини, було встановлено, що на дослідних ділянках № 1 та № 2 спостерігається значне посилення ростових процесів в порівняні з контрольним зразком, 
при цьому на дослідній ділянці №3 фіксується значне пригнічення ростових процесів кореневої частити в порівнянні з контролем.

У ході дослідження нами було визначено фітотоксичний ефект, який визначали у відсотках за певними біопараметрами: висотою надземної частини, кореневої частини, сирою та сухою біомасою пагона та кореня. Так, в таблиці 1 наведені основні дані, щодо утворення фітотоксичного ефекту у тест-рослин.

Таблиця 1

Фітотоксичний ефект за основними біопараметрами біоіндикаторної культури (Triticum vulgare L)

\begin{tabular}{|c|c|c|c|}
\hline \multirow{2}{*}{ Параметри } & \multicolumn{3}{|c|}{ Досліджувані ділянки } \\
\hline & № 1 & № 2 & № 3 \\
\hline$\Phi E_{1}$ (за висотою пагона), \% & $6 \%$ & $12 \%$ & $31 \%$ \\
\hline$\Phi \mathrm{E}_{2}$ (за біомасою пагона), \% & $26 \%$ & $40 \%$ & $13 \%$ \\
\hline $\begin{array}{c}\Phi_{3} \text { (за сухою біомасою } \\
\text { пагона), \% }\end{array}$ & $75 \%$ & $23 \%$ & $11 \%$ \\
\hline ФЕ 4 (за довжиною кореня), \% & $9 \%$ & $2 \%$ & $45 \%$ \\
\hline ФЕ $\mathrm{E}_{5}$ (за біомасою кореня), \% & $50 \%$ & $5,5 \%$ & $10 \%$ \\
\hline $\begin{array}{c}\Phi \mathrm{E}_{6} \text { (за сухою біомасою } \\
\text { кореня), \% }\end{array}$ & $86 \%$ & $89 \%$ & $9 \%$ \\
\hline ФЕ 7 (середнє значення), \% & $42 \%$ & $29 \%$ & $20 \%$ \\
\hline
\end{tabular}

Аналізуючи фітотоксичний ефект за основними біопараметрами, було встановлено, що мінімальний відсоток токсичності за висотою пагона зафіксовано на дослідній ділянці № 1, максимальне значення i відповідно_пригнічення фіксувалось у біоіндикаторної культури на дослідній ділянці №3.

Фітотоксичний ефект визначений за сирою біомасою пагона був в межах від 13\% до 40\%, на дослідній ділянці №3 та №2 відповідно, при цьому за сухою біомасою надземної частини мінімальне пригнічення фіксувалось на дослідній ділянці №3, а максимальний фітотоксичний ефект проявився на ділянці №1 та складає 75\%.

При аналізі фітотоксичного ефекту, на сиру біомасу кореня, фіксувалось від 5,5\% на дослідній ділянці №2 до 50\% на ділянці №1. Значний прояв токсичності зразків води спостерігалося на сухій біомасі 
кореневої частини на ділянці № 1 та № 2 - 86\% та 89\%, при цьому мінімальне - 9\% на дослідній ділянці № 3 .

Визначення середнього значення фітотоксичного ефекту за всіма шістьома показниками, було отримано наступні дані: $42 \%$ на дослідній ділянці № 1, що вказує на забруднення води вище середнього. При цьому на дослідній ділянці № 2 та № 3 середній фітотоксичний ефект склав $29 \%$ та $20 \%$ відповідно, що вказує на середній рівень забруднення води р. Альта.

За результатами проведеного дослідження було зроблено наступні висновки:

1. Визначено, що основне забруднення поверхневих вод України в цілому та малих річок безпосередньо спричинено надходженням зворотних стічних вод промислових підприємств та комунальних господарств, поверхневим стоком 3 урбанізованих територій, промислових об'єктів, транспортних шляхів та сільськогосподарських угідь.

2. Проведений аналіз річкової мережі Київської області свідчить про неоднорідність розподілу водних ресурсів. На балансі водогосподарських організацій у Київській області на середніх та малих річках утримується 18 водосховищ, 36 ставків та 1117,77 км річкової системи.

3. Досліджено, що основними причинами деградації екосистеми р. Альта в межах м. Переяслав є: пересихання водойми, заростання самосійними деревами, кущами, високорослою болотною рослинністю, сильне замулення.

\section{Література:}

1. Гриб Й.В. Відновна гідро екологія порушення річкових та озерних систем (гідрохімія, гідробіологія, гідрологія). Рівне: Волинські обереги, 1999. - 348 с.

2. Давидова С.В. Водна токсикологія: основні теоретичні положення та їхнє практичне застосування [Монографія]. - К.: Вид-во Українського фіто соціологічного центру, 2013. - 295 с.

3. Дідух Я. П. Фітоіндикація екологічних факторів. Київ: Наук. думка, 1994. $280 \mathrm{c.}$

4. Игошин Н. И. Проблемы восстановления и охраны малых рек и водоемов. Гидроэкологические аспекты. Учебное пособие. Харьков: Бурун Книга, 2009. 240 с. 
5. Клименко М.О., Статник I.I. Охорона водних об'єктів від антропогенного впливу. Вісник КНУ імені Михайла Остроградського. Кременчук, 2010. Вип. 6/2010 (65). Ч. 1. С. 177-181.

6. Клименко М.О., Гроховська Ю.Р. Порівняльна характеристика результатів оцінки якості води за гідрохімічними показниками та водною рослинністю. Вісник РДТУ. Рівне, 2001. Вип. 3(10). С. 15-22.

7. Клименко М.О., Гроховська Ю.Р. Відновна гідроекологія порушених річкових та озерних систем (гідрохімія, гідробіологія, гідрологія, управління). Рівне, 2004. - 211 с.

DOI https://doi.org/10.30525/978-9934-26-183-1-9

\title{
ОСОБЛИВОСТІ ФІЗІОЛОГІЧНОГО СТАНУ EICHHORNIA CRASSIPES (MART.) SOLMS. ЗА РІЗНИХ ТЕМПЕРАТУР СЕРЕДОВИЩА
}

\author{
Красюк Ю. М. \\ кандидат біологічних наук, \\ науковий співробітник \\ Інститут гідробіології Національної академії наук Украӥни \\ м. Київ, Украӥна
}

Водяний гіацинт або ейхорнія (Eichhornia crassipes) через свої особливості може використовуватись в різних сферах призначення. Так, ейхорнія має високий вміст білку, що дає можливість застосовувати ії як сидерат, компост і мульчу для поліпшення грунту. Багато досліджень було присвячено використанню цієї рослини в якості кормового матеріалу для худоби [9, с. 965-972; 11].

Eichornia crassipes, через здатність інтенсивно поглинати та накопичувати нітрати, фосфати, феноли, тяжкі метали та інші шкідливі речовини, використовується для очищення забруднених вод [1, с. 48-50; 6, с. 155-160].

Ейхорнія росте у прісних водоймах (мілководні ставки, болота, невеликі струмки, озера та річки) за умови, що вони не засолені або не стають солоними під час посухи. Найсприятливіші температурні умови - від 14 до $29^{\circ} \mathrm{C}$, а перешкоджають ії розвитку - температури нижче $13^{\circ} \mathrm{C}[7]$. 